\title{
Experimental model for alkalic chloride-rich mantle liquids
}

\author{
Oleg G. Safonov ${ }^{1}$, Leonid L. Perchuk ${ }^{2}$, Yuriy A. Litvin ${ }^{1}$, Nadezhda V. Chertkova ${ }^{2}$ \\ ${ }^{1}$ Institute of Experimental Mineralogy, Chernogolovka, Russia; oleg@iem.ac.ru \\ ${ }^{2}$ Department of Petrology, Moscow State University, Moscow, Russia
}

\section{INTRODUCTION}

Potassium and chlorine-rich inclusions in diamonds were firstly recognized in Chinese kimberlites (Chen et al., 1992), while positive correlation between $\mathrm{K}$ and $\mathrm{Cl}$ was reported for Yakutian, Botswanian, and Canadian diamonds (e.g. Johnson et al., 2000). Izraeli et al. (2001) firstly published data on individual chloriderich inclusions in cloudy diamonds from the Koffiefontein pipe, S. Africa. They interpreted these inclusions as relics of quenched liquids, whose composition correspond to mixtures of alkali chlorides (predominately, $\mathrm{KCl}$ ) and carbonates with varying contents of $\mathrm{H}_{2} \mathrm{O}$ and silicates. Similar chloridecarbonate inclusions were recently described in diamonds from Canada (Diavik: Klein-BenDavid et al., 2004, 2006, 2007; Panda: Tomlinson et al., 2006). The chloride-carbonate relics in diamonds are closely associated with both eclogitic and peridotitic minerals, as well as with the phases produced from mineralliquid reactions (Izraeli et al., 2004; Klein-BenDavid et al., 2006; Tomlinson et al., 2006, 2007). These data indicate an active interaction of the liquids with the upper mantle mineral assemblages. Data by Zedgenizov et al. (2007a) on chloride-carbonate inclusions in diamonds from the eclogite xenolith of the Udachnaya kimberlite, Siberia, clearly showed that the chloride-carbonate liquids interacted with the mantle rocks before the production of the kimeberlite melt and were closely related to kimberlite evolution. This conclusion perfectly agrees with the data on chloride-carbonate inclusions in groundmass olivines of these kimberlites (Kamenetsky et al., 2004, 2007).

The chloride-carbonate liquids are compositionally linked to alkalic silicate, carbonate-silicate, and carbonate Cl-bearing liquids trapped in diamonds worldwide (Navon et al., 1988, 2003; Schrauder, Navon, 1994; Shiryaev et al., 2005; Zedgenizov et al., 2007b). This link between the above types of liquids is illustrated in Figure 1 (Safonov et al., 2007a). Continuous trends between silicate and carbonate inclusions, from one side, and between chloride-rich and carbonate inclusions, from another side, suggest a complete miscibility of the corresponding liquids at the upper mantle conditions. A lack of links between carbonate-silicate and carbonate-chloride liquids suggests an existence of a wide miscibility gap between these liquids at the upper mantle P-T (Fig. 1).

In order to substantiate the "immiscibility" model following from the above data, we performed experiments on chloride-carbonate-silicate systems at pressures about $5 \mathrm{GPa}$, i.e. a mean pressure deduced for the inclusions (Izraeli et al., 2004; Zedgenizov et al., 2004; Tomlinson et al., 2006).

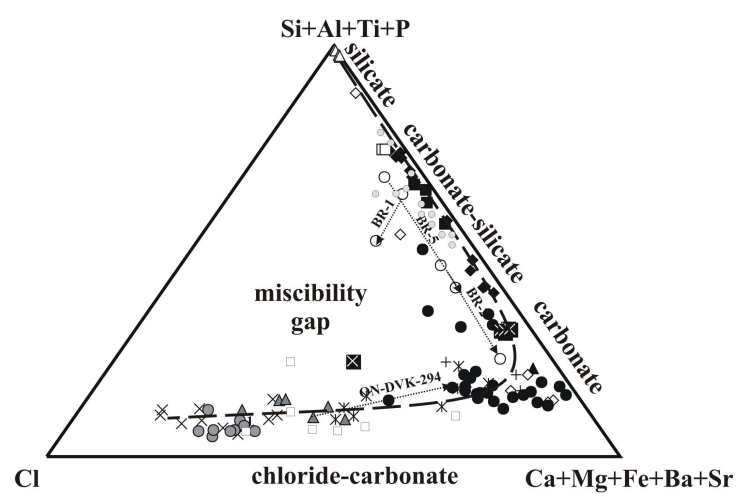

Fig. 1. Compositions of alkalic chloride-bearing liquids trapped in diamonds. Trends for diamonds BR-1, BR-2, BR-5 (Shiryaev et al., 2005) and ON-DVK-294 (Klein-BenDavid et al., 2004) are discussed in the text. References for used data sets see in Safonov et al. (2007).

\section{EXPERIMENTAL STUDY OF THE CHLORIDE- CARBONATE-SILICATE SYSTEMS}

$\mathrm{CaMgSi}_{2} \mathrm{O}_{6}-\left(\mathrm{Na}_{2} \mathrm{CO}_{3}, \mathrm{CaCO}_{3}\right)-\mathrm{KCl}$. Experiments in this model system at $5 \mathrm{GPa}$ fully supported the above model (Safonov et al., 2007a). They revealed a wide miscibility gap between Cl-bearing carbonatesilicate $\left(L_{\mathrm{CS}}\right)$ and Si-bearing chloride-carbonate $\left(L_{\mathrm{CC}}\right)$ melts. Crystallization of silicates within broad compositional range shifts the $L_{\mathrm{CS}}$ and $L_{\mathrm{CC}}$ compositions along the gap boundaries toward the lowtemperature carbonate region. Cooling at constant pressure results in displacement of the $L_{\mathrm{CS}}+L_{\mathrm{CC}}$ interval toward the more silica-rich portion of the system, while the interval of homogeneous $L_{\mathrm{CC}}$ coexisting with silicates expands. Schematic cross section of the ternary system (Fig. 2) indicates three petrologically significant temperature intervals: $L_{\mathrm{CC}}+S, L_{\mathrm{CC}}+L_{\mathrm{CS}}+S$, and $L_{\mathrm{CC}}+L_{\mathrm{CS}}$.

Contrast compositions of silicates and $L_{\mathrm{CC}}$ inevitably would result in active reactions between them within the fist $\mathrm{T}-\mathrm{X}$ interval. Before the appearance of the immiscible $L_{\mathrm{CC}}$ and $L_{\mathrm{CS}}$ at higher temperature, these reactions would modify both the resulting mineral assemblages and the composition of the melts. It is evident that progress of the reactions would be greatly dependent both on silicate composition and carbonate/chloride ratio in the melt. In order to investigate an interaction of silicates with the chloride-carbonate melts and a mutual role of chlorides and carbonates in these reactions, additional runs 
involving model end-members and natural minerals were performed.

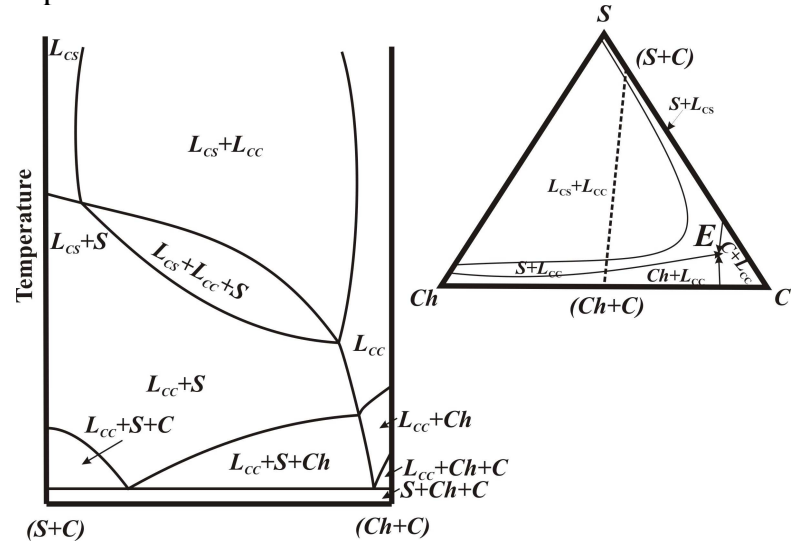

Fig. 2. Schematic $T-X$ section of the pseudo-ternary system chloride $(\mathrm{Ch})$-carbonate $(C)$-silicate $(S)$ with the wide miscibility gap along an arbitrary join (silicate+carbonate)(chloride+carbonate) (dashed line) at constant pressure.

$\mathrm{Mg}_{2} \mathrm{SiO}_{4}-\left(\mathrm{Na}_{2} \mathrm{CO}_{3}, \mathrm{CaCO}_{3}\right)-\mathrm{KCl}$. Fig. 3 shows phase relations during the interaction of forsterite $(\mathrm{Fo})$ with the $L_{C C}$, whose composition corresponds to the mix. 7. The sequence of phase assemblages perfectly matches the scheme in fig. 2. Immiscible $L_{C S}{ }^{(1)}$ and $L_{C C}{ }^{(1)}$ coexist at $1510^{\circ} \mathrm{C}$ (Fig. 4). As crystallization of $F_{O}$ begins $\left(1450^{\circ} \mathrm{C}\right)$, compositions of $L_{C S}{ }^{(2)}$ and $L_{C C}{ }^{(2)}$ are displaced toward the carbonate-rich $(\mathrm{Na}+\mathrm{Ca}+\mathrm{Mg})$ apex. At lower temperatures, $F o( \pm M r w)$ coexists with the single $L_{C C}$ (Fig. 4). It is evident that the Cacarbonate component is a leading factor in reactions of $F o$, i.e. $F o+\left[\mathrm{CaCO}_{3}\right]=\left[2 \mathrm{MgO}+\mathrm{CaSiO}_{3}+\mathrm{CO}_{2}\right]$ or $2 \mathrm{Fo}+3\left[\mathrm{CaCO}_{3}\right]=\mathrm{Mrw}+\left[3 \mathrm{MgO}+3 \mathrm{CO}_{2}\right]$. Chloride does not participate in the reactions, but creates a possibility for the liquid immiscibility between $L_{\mathrm{CC}}$ and $L_{\mathrm{CS}}$ at higher temperature.

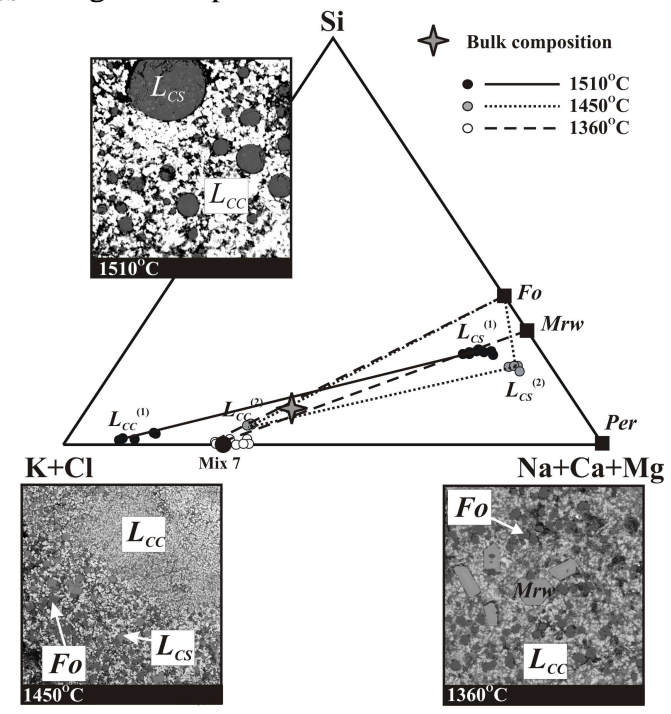

Fig. 3 Phase relations in the system [mix 7$]_{71} \mathrm{Fo}_{29}$ at $5 \mathrm{GPa}$.

Similar sequence is observed for the system $\mathbf{M g S i O}_{3^{-}}$ $\left(\mathrm{Na}_{2} \mathrm{CO}_{3}, \mathrm{CaCO}_{3}\right)-\mathrm{KCl}$ In this first system, the assemblage $\mathrm{Fo}+\mathrm{Di} \pm \mathrm{Mrw}\left(3 \mathrm{En}+\mathrm{CaCO}_{3}=\mathrm{Fo}+\mathrm{Di}+\right.$ $\mathrm{CO}_{2}$ ) coexisting with a single $L_{C C}$ in this system below $1450^{\circ} \mathrm{C}$ suggests that chloride again does not participate in "dissolution" of enstatite $(E n)$.
Another situation is deduced for the systems involving pyrope and jadeite. Pyrope have not been observed in any run product in the system $\mathrm{Mg}_{3} \mathrm{Al}_{2} \mathrm{Si}_{3} \mathrm{O}_{12}-\left(\mathrm{CaCO}_{3}, \mathrm{Na}_{2} \mathrm{CO}_{3}\right)-\mathrm{KCl}$. In the case of starting $L_{\mathrm{CC}}$ corresponding to mix.6 (Fig. 4), liquidus spinel $(S p l)$ coexists with two melts at $1500^{\circ} \mathrm{C}$. At $1400-1300^{\circ} \mathrm{C}$, it gives place to $\mathrm{Fo}( \pm \mathrm{Cl}$-bearing $\mathrm{Phl}$ ) via reaction of $S p l$ with highly-K chloride-rich liquid, because of a strong affinity of $\mathrm{Al}$ to $\mathrm{K}$ in the melt (the trend $L_{\mathrm{CS}}{ }^{(1)} \rightarrow L_{\mathrm{CS}}{ }^{(3)}$ in fig. 5 is directed toward the enrichment of $L_{\mathrm{CS}}$ in $\mathrm{K}$ and $\mathrm{Cl}$ ). In the case of starting $L_{\mathrm{CC}}$ corresponding to mix.7 (Fig. 4), no $\mathrm{Spl}$ is observed at high temperature, while $F o$ is still present. At $1360^{\circ} \mathrm{C}$, it coexists with homogeneous chloride-rich melt, enriched also in $\mathrm{Si}$ and $\mathrm{Al}$ (reflected in mice-like phase in the products of melt quenching).

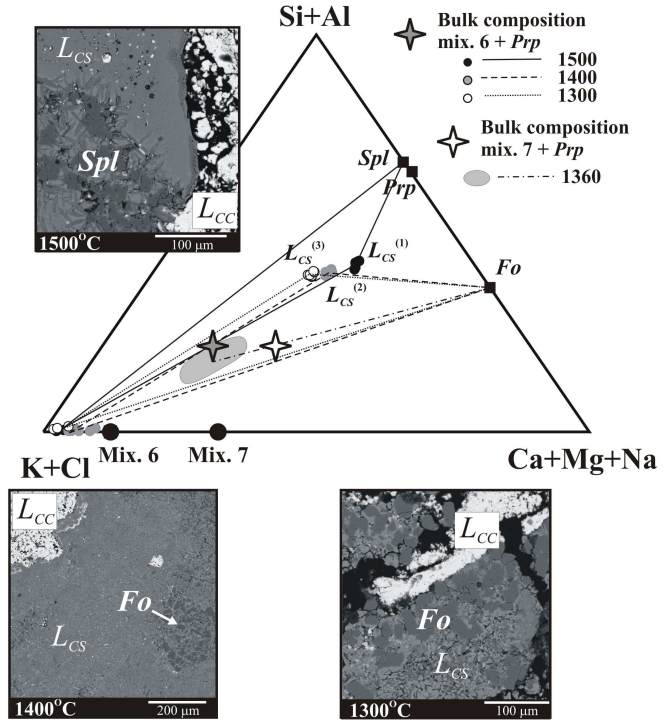

Fig. 4 Phase relations in the systems [mix 6] $]_{71} \mathrm{FO}_{29}$ and [mix $7]_{71} \mathrm{Fo}_{29}$ at $5 \mathrm{GPa}$.

Close trends are characteristic for the system $\mathrm{CaMgSi}_{2} \mathrm{O}_{6}-\mathrm{NaAlSi}_{2} \mathrm{O}_{6}-\left(\mathrm{CaCO}_{3}, \mathrm{Na}_{2} \mathrm{CO}_{3}\right)-\mathrm{KCl}$ : two liquids coexist at temperatures $>1500^{\circ} \mathrm{C}$, while appearance of $C p x$ and $M r w$ at lower temperatures results in accumulation of $\mathrm{Si}$ and $\mathrm{Al}$ simultaneously with $\mathrm{K}$ and $\mathrm{Cl}$ in the residual $L_{\mathrm{CS}}$. At $\sim 1350^{\circ} \mathrm{C}$, an assemblage Cpx+Mrw+Ca-Grt coexists with homogeneous $L_{\mathrm{CC}}$. Similar to the system with pyrope, this low-temperature homogeneous $L_{\mathrm{CC}}$ is characterized by elevated concentrations of $\mathrm{Si}$ and $\mathrm{Al}$.

The above examples clearly indicate difference between reactions of the chloride-carbonate melts with peridotite-related silicates and eclogite-related silicates. The reason for it is peculiarities of the chloride-silicate boundary joins. The $D i(F o, E n)-\mathrm{KCl}$ joins are nearly binary systems with high-T (> 1700-1800 ${ }^{\circ} \mathrm{C}$ ) liquid immiscibility and no reaction of silicates with $\mathrm{KCl}$ melt (e.g. Safonov et al., 2007b). In contrast, the join $J d$ $\mathrm{KCl}$ is a pseudobinary system, where strong $\mathrm{K}-\mathrm{Na}$ exchange between silicate and chloride results in formation of K-rich aluminosilicate melt, coexisting with $\mathrm{K}-\mathrm{Na}$ chloride melt at $1250-1300^{\circ} \mathrm{C}$ at $5 \mathrm{GPa}$ (Safonov et al., 2007b). The join Prp- $\mathrm{KCl}$ at $5 \mathrm{GPa}$ is also pseudobinary, where $\mathrm{Spl}$ and $\mathrm{Fo}_{0}$ form in 
equilibrium with Si-Al-rich silicate melt and $\mathrm{Mg}$ enriched chloride liquid.

\section{APPLICATION OF THE EXPERIMENTAL RESULTS TO THE EVOLUTION OF MELTS INCLUDED IN DIAMONDS.}

Schrauder, Navon (1994), Shiryaev et al. (2005), Zedgenizov et al. (2007b) showed that compositions of the carbonate-silicate liquids included in some diamonds varies from the $\mathrm{SiO}_{2}$-enriched melts to the $\mathrm{SiO}_{2}$-depleted $\mathrm{CaO}$-rich melts. For example, an evolution of inclusions in the Brazilian diamonds BR-5 and BR-2 (Shiryaev et al., 2005) (Fig. 1) resembles the trend of the evolution of the synthetic melts $L_{\mathrm{CS}}{ }^{(1)}-L_{\mathrm{CS}}{ }^{(2)}$ in Fig. 3 and the trends of $L_{\mathrm{CS}}$ evolution in the system $\mathrm{CaMgSi}_{2} \mathrm{O}_{6}-\left(\mathrm{CaCO}_{3}, \mathrm{Na}_{2} \mathrm{CO}_{3}\right)-\mathrm{KCl}$ (Safonov et al., 2007). Another type of the evolutionary trend in the diamond BR-1 (Fig. 1) it could be resulted from an intensive fractionation of olivine (Shiryaev et al., 2005). This suggestion is remarkably supported with the experiments in the system $\operatorname{Prp}-\left(\mathrm{CaCO}_{3}, \mathrm{Na}_{2} \mathrm{CO}_{3}\right)$ $\mathrm{KCl}$ (Fig. 4): the decrease of temperature is accompanied by $F_{O}$ precipitation, while the melt becomes richer in $\mathrm{K}$ and $\mathrm{Cl}$. Thus, both trends reflect silicate crystallization from the Cl-bearing carbonatesilicate melt during cooling. Following to the experiments, it can be assumed that two types of trends for liquids in the Brazilian diamonds are resulted from different mineral environments of their growth, i.e. peridotitic for BR-5 and BR-2, and eclogitic for BR-1.

An evolution of inclusions in diamond ON-DVK294 from the Diavik pipe, Canada (Klein-BenDavid et al., 2004) proceeds from the chloride-carbonate liquid the inner zone to the carbonatitic liquid in the outer zone (Fig. 1). Taking to account compositions of the chloride-carbonate liquids in other diamonds of the Diavik pipe (Klein-BenDavid et al., 2006, 2007), a single trend appears. This trend is consistent with the evolution of the chloride-carbonate liquids in the systems $\mathrm{CaMgSi}_{2} \mathrm{O}_{6}-\left(\mathrm{CaCO}_{3}, \quad \mathrm{Na}_{2} \mathrm{CO}_{3}\right)-\mathrm{KCl}$ and $\mathrm{Mg}_{2} \mathrm{SiO}_{4}-\left(\mathrm{CaCO}_{3}, \mathrm{Na}_{2} \mathrm{CO}_{3}\right)-\mathrm{KCl}\left(L_{\mathrm{CC}}{ }^{(1)}-L_{\mathrm{CC}}{ }^{(2)}\right.$ in fig. 3) and corresponds to the diamond growth during cooling.

Following to the experimental results, $\mathrm{K}$ and $\mathrm{Cl}$ rich carbonate liquids in diamonds of the Udachnaya pipe (Zedgenizov et al., 2007b) can be considered as low-temperature liquids. Nevertheless, they could evolve from the primary carbonate-silicate melts equilibrated with the immiscible chloride-carbonate liquids, whose relics were found in diamonds of the eclogite xenolith (Zedgenizov et al., 2007a) and in groundmass olivines (Kamenetsky et al., 2004) from this pipe.

Tomlinson et al. (2006) identified compositional differences in chloride-carbonate liquids coexisting with peridotitic and eclogites phases in diamonds from the Panda pipe (Canada). The compositions of the "peridotitic" liquids are located along the chloridecarbonate join of the ternary system, while "eclogitic" liquid is enriched in $\mathrm{Al}$ and $\mathrm{Si}$. This difference is reproduced in our experiments, as well.
Chen, F., Guo, J., Chen, C., Liu, C., 1992. High-K and high$\mathrm{Cl}$ inclusions in diamond and mantle metasomatism, Acta Mineralogica Sinica 12, 193-198.

Johnson, L.H., Burgess, R., Turner, G., Milledge, H.J., Harris, J.W., 2000. Noble gas and halogen geochemistry of mantle fluids: comparison of African and Canadian diamonds, Geochimica et Cosmochimica Acta 64, 717732.

Kamenetsky, M.B., Sobolev, A.V., Kamenetsky, V.S., Maas, R. et al., 2004. Kimberlite melts rich in alkali chlorides and carbonates: A potent metasomatic agent in the mantle. Geology 32, 845-848.

Kamenetsky, V.S., Kamenetsky, M.B., Sharygin, V.V., Faure, K., Golovin, A.V., 2007. Chloride and carbonate immiscible liquids at the closure of the kimberlite magma evolution (Udachnaya-East kimberlite, Siberia). Chemical Geology 237, 384-400.

Izraeli, E.S., Harris, J.W., Navon, O., 2001. Brine inclusions in diamonds: a new upper mantle fluid. Earth and Planetary Science Letters 5807, 1-10.

Izraeli, E.S., Harris, J.W., Navon, O., 2004. Fluid and mineral inclusions in cloudy diamonds from Koffiefontein, South Africa. Geochimica et Cosmochimica Acta. 68, 2561-2575.

Klein-BenDavid, O., Izraeli, E.S., Hauri, E., Navon, O. 2004. Mantle fluid evolution - a tale of one diamond. Lithos 77, 243-253.

Klein-BenDavid, O., Wirth, R., Navon, O., 2006. TEM imaging and analysis of microinclusions in diamonds: a close look at diamond-bearing fluids. American Mineralogist 91, 353-356.

Klein-BenDavid, O., Izraeli, E.S., Hauri, E., Navon, O., 2007. Fluid inclusions in diamonds from the Diavik mine, Canada and the evolution of diamond-forming fluids. Geochimica et Cosmochimica Acta 71, 723-744.

Navon, O., Hutcheon, I.D., Rossman, G.R., Wasserburg, G.J. 1988. Mantle-derived fluids in diamond micro-inclusions. Nature 335, 784-789.

Navon, O., Izraeli, E.S., Klein-BenDavid, O., 2003. Fluid inclusions in diamonds - the carbonatitic connection. $8^{\text {th }}$ Inernational Kimberlite Conference Long Abstract: FLA_0107.

Safonov, O.G., Perchuk, L.L., Litvin, Yu.A., 2007a. Melting relations in the chloride-carbonate-silicate systems at highpressure and the model for formation of alkalic diamondforming liquids in the upper mantle. Earth and Planetary Science Letters 253, 112-128.

Safonov, O.G., Perchuk, L.L., Litvin, Yu.A., $2007 b$. Interaction of diopside and jadeite with potassium chloride at pressure 5 GPa. Doklady Earth Sciences 415, 789-793.

Schrauder, M., Navon, O., 1994. Hydrous and carbonatitic mantle fluids in fibrous diamonds from Jwaneng, Botswana. Geochimica et Cosmochimica Acta 58, 761771.

Shiryaev, A.A., Izraeli, E.S., Hauri, E.H., Zakharchenko, O.D., Navon, O., 2005. Chemical, optical and isotopic investigation of fibrous diamonds from Brazil. Russian Geology and Geophysics 46, 1185-1201.

Tomlinson, E.L., Jones, A.P., Harris, J.W., 2006. Co-existing fluid and silicate inclusions in mantle diamond. Earth and Planetary Science Letters 250, 581-595.

Zedgenizov, D.A., Ragozin, A.L., Shatsky, V.S., 2007a. Chloride-carbonate fluid in diamonds from the eclogite xenolith. Doklady Earth Sciences 415, 961-964.

Zedgenizov, D.A., Rege, S., Griffin, W.L., Kagi H., Shatsky, V.S. 2007b. Compositional variations of micro-inclusions in fluid-bearing diamonds from Udachnaya kimberlite pipe as revealed by LA-ICP-MS. Chemical Geology 240, 151162. 